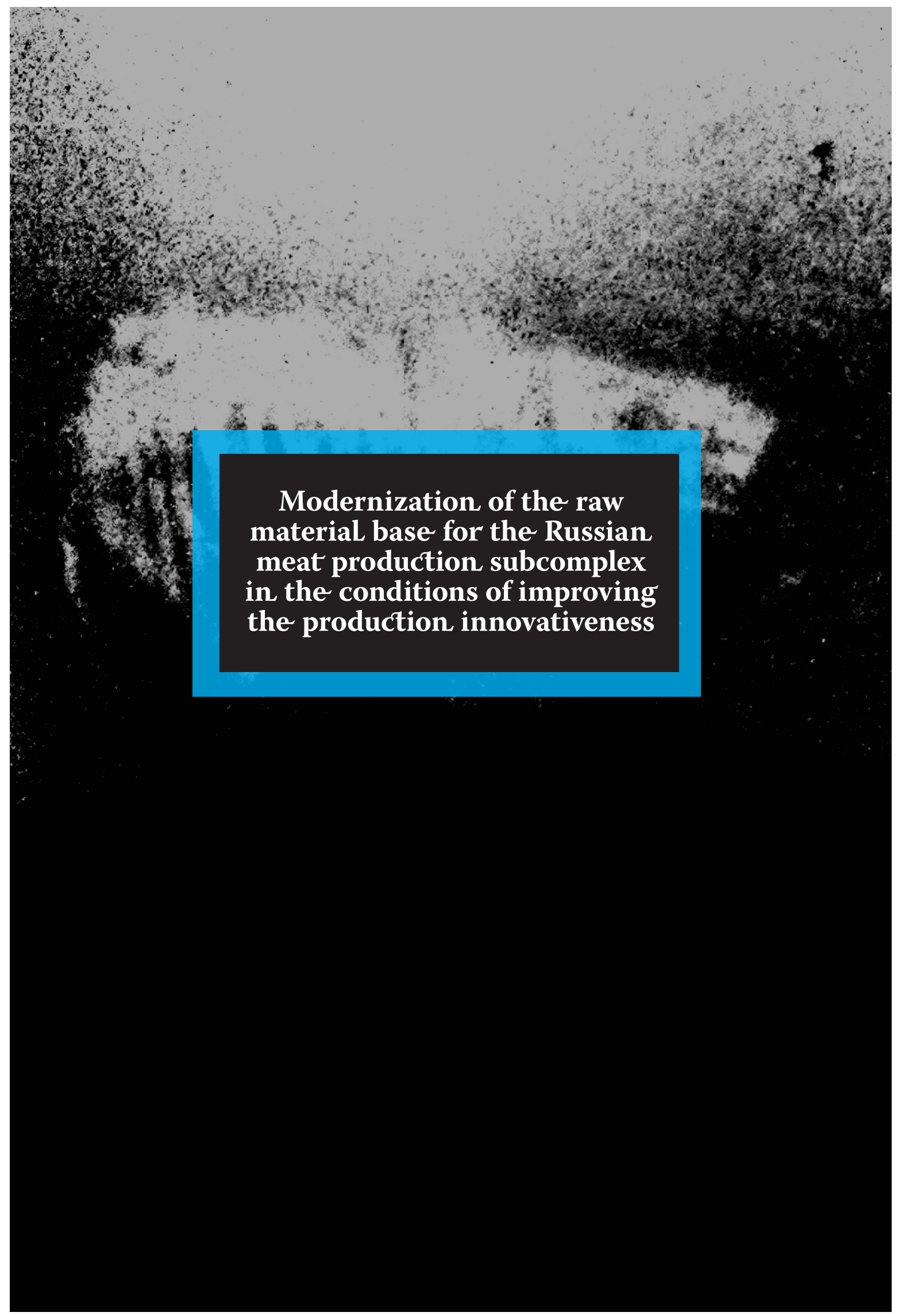




\title{
MODERNIZATION OF THE RAW MATERIAL BASE FOR THE RUSSIAN MEAT PRODUCTION SUBCOMPLEX IN THE CONDITIONS OF IMPROVING THE PRODUCTION INNOVATIVENESS
}

\section{MODERNIZACIÓN DE LA BASE DE MATERIAS PRIMAS PARA EL SUBCOMPLEJO DE PRODUCCIÓN DE CARNE RUSA EN LAS CONDICIONES PARA MEJORAR LA INNOVACIÓN DE LA PRODUCCIÓN}

\author{
Authors \\ A.V. Kotarev. Federal State Budgetary Educational Institution of Higher Education "Voronezh State \\ Agrarian University named after Emperor Peter I'. Russia. \\ E-mail:kotarew@gmail.com \\ I.N. Vasilenko. Federal State Budgetary Educational Institution of Higher Education "Voronezh State \\ University of Engineering Technologies”. Russia. \\ E-mail: Irina_NW@bk.ru
}

A.O. Kotareva. Federal State Budgetary Educational Institution of Higher Education "Voronezh State Agrarian University named after Emperor Peter I'. Russia.

E-mail: kotareva@gmail.com

A.F. Dorofeev. Federal State Budgetary Educational Institution of Higher Education "Belgorod State Agrarian University named after V.Ya. Gorin”. Russia.

E-mail:571062@,rambler.ru

V.N. Lebed. Federal State Budgetary Educational Institution of Higher Education “Belgorod State Agrarian University named after V.Ya. Gorin"..Russia.

Fecha de recibido: 13 de noviembre de 2019

Fecha de aceptado para publicación: 30 de noviembre de 2019

Fecha de publicación: 10 de diciembre de 2019

\begin{abstract}
We set a goal for the study to explore the issues on the development of the beef stock farming sector in the agro-industrial complex of the Russian Federation in the context of comprehensive modernization and increasing the innovativeness level of the industry segment. Being based on modern research methods (analysis, idealization, abstraction, synthesis and concretization), we have found that the category of "innovation" determines the practical application of qualitatively new scientific and technological, organizational and economic, manufacturing and/or other solutions, which provide breakthrough development and/or qualitative and quantitative changes of high intensity for a process and/or phenomenon (positive synergy). It was found by us that the key problems of beef stock farming are: high physical deterioration and obsolescence of durable equipment; low provision of complete feed; lack of qualified personnel; low commitment to innovative solutions; dependence of technical and technological support on imports; low availability of financial resources, especially for small businesses; lack of genetic selection work; underdevelopment of cooperation processes; high resource consumption rates. During the study, issues of information support for the modernization of beef stock farming on the basis of a single information resource of CALS-technologies and SLBE-tools have been explored, as well as ways to reduce labour costs, increase conversion, and weight gain rates and safety of farm animals in meat industry enterprises were suggested.
\end{abstract}

Keywords: beef stock farming, meat production subcomplex, management, modernization, innovative development.

Establecimos una meta para el estudio para explorar los problemas en el desarrollo del sector ganadero de carne en el complejo agroindustrial de la Federación de Rusia en el contexto de la modernización integral y el aumento del nivel de innovación del segmento de la industria. Al estar basados en métodos de investigación modernos (análisis, idealización, abstracción, síntesis y concreción), hemos encontrado que la categoría de "innovación" determina la aplicación práctica de soluciones cualitativamente nuevas científicas y tecnológicas, organizativas y económicas, de fabricación y / u otras, que proporcionan un desarrollo innovador y / o cambios cualitativos y cuantitativos de alta intensidad para un proceso y / o fenómeno (sinergia positiva). Descubrimos que los problemas clave de la ganadería de carne son: alto deterioro físico y obsolescencia de equipos duraderos; baja provisión de alimento completo; falta de personal calificado; bajo compromiso con soluciones innovadoras; dependencia del soporte técnico y tecnológico de las importaciones; baja disponibilidad de recursos financieros, especialmente para pequeñas empresas; falta de trabajo de selección genética; subdesarrollo de 
procesos de cooperación; altas tasas de consumo de recursos. Durante el estudio, se exploraron cuestiones de apoyo de información para la modernización de la ganadería de carne de res sobre la base de un único recurso de información de tecnologías CALS y herramientas SLBE, así como formas de reducir los costos laborales, aumentar la conversión y aumentar de peso Se sugirieron las tasas y la seguridad de los animales de granja en las empresas de la industria cárnica.

Palabras clave: ganadería de carne, subcomplejo de producción de carne, gestión, modernización, desarrollo innovador.

\section{Introduction}

In the modern market management conditions, beef stock farming as a structural element of the meat production subcomplex is developing at a fairly steady pace. Currently, due to the implementation of the State Program for the Development of Agriculture for 2013-2020 and a number of subordinate programs at the federal and regional levels, positive dynamics of production in the beef stock farming is maintained; growth is ensured to a greater extent due to the sustainable development of the pig and poultry husbandries.

So, in 2017, 14.6 million tons of livestock and poultry have been produced for slaughter (live weight basis) (104.7\% compared to 2016), and in comparison with 2012, this figure increased by $25.8 \%$ ( 3 million tons). The increase in beef stock farming production was mainly achieved both by increasing the productivity of animals through improving housing and feeding conditions (complete diets, the quality of feed mixtures, rationing feed distribution, regulating microclimate parameters) and increasing livestock by introducing new production facilities and modernization of the existing ones. At the same time, the scale of construction of new complexes, as well as the modernization of already functioning enterprises, were insignificant, which had a negative effect on the development strategy of this industry segment.

Despite the stated positive development trend, modern beef stock farming complexes face serious problems that impose considerable limitations on the sustainability and balance of its development. In particular, the high intensity of changes in terms of the technical and technological support of the livestock and feed production sector, the monopolization of the market, the acute struggle for potential buyers, the need for and prospects for improving the quality and safety of products, imperfect competition and its growth, orient industry actors to raise questions and solve problems in the field of organization, planning, control, evaluation and regulation in a new format, which takes into account the innovation factor. Thus, the lack of funds, depreciation of basic production assets, especially their active part, as well as the entire material and technical base, problems with lending, inefficiency and low practical importance of legislative and financial support from the state, limited free funds, imbalance in the procurement system and monetary distribution between the participants of the food production vertical, the lack of development and improvement of the cooperative processes and the selection base are serious factors of the intensive development of domestic beef stock farming.

In this context, it is worth noting that the beef stock farming sector is not only a systemforming link in the entire meat-producing subcomplex, but is also the main stabilizing factor in the preservation of rural settlements and the territorial integrity of Russia as a country. About 30.8 million people live in rural areas today. Compared with 1990, the rural population has decreased by almost 1 million people. From the population living in rural areas, 6.5-6.6 million people are employed in agricultural production, hunting and forestry 
against 9.9 million in 1990, of which 3.5-3.6 million people in the cattle-breeding sector. All this confirms not only the high economic significance of the progressive development of this industry segment but also the social need for its improvement $[6,9,22]$.

It should be noted that the potential of modern domestic beef stock farming is largely determined by the state of the breeding base. Currently, about 2.5 thousand herds of breeding farm animals are registered in the state breeding register. The needs of agricultural producers in high-quality young breeder-feeder are met at the expense of national reproduction and imports. The realization of young breeder-feeder livestock of the meattype productivity in 2017 amounted to 33.6 thousand heads $(132.3 \%)$, pigs - 94.5 thousand heads $(124.7 \%)$, sheep and goats -182.1 thousand heads $(122.2 \%)$. It is worth emphasizing that this issue should be constantly monitored by the government sectoral agencies since this area is considered the most vulnerable from the standpoint of import dependence and strengthening the food sovereignty of Russia.

Today, at the state level, a strategic program of innovative development of various branch areas in the agro-industrial complex of the Russian Federation is legislatively defined and secured, which proves the high degree of scientific and practical significance of the stated research topic for our study and determines the conceptual logic of the structure and the formation progress for the substance of this scientific research.

\section{Goals and Objectives}

The basic goal of this research is the study, exploration and development of scientifictheoretical and applied issues regarding the sustainable and balanced development of the raw material base of the meat production subcomplex (beef stock farming) in terms of increasing the level of innovativeness and efficiency of the relevant business entities. In the context of the goal, the following objectives were accomplished: the basic category of the subject of research was clarified out from the perspective of domestic and foreign experience; the analysis and assessment of the socio-economic problems concerning the development of the branch segment of the meat production subcomplex; The organizational and economic component, the methodology of implementation and the information support of the program for the modernization of the beef stock farming sector have been also worked out.

\section{Methods and Materials}

The basic research was made with the use of theoretical, methodical and applied theories and concepts of domestic and foreign scientists regarding the provision of innovative development of business entities. During the study, the following methods of cognition were applied: analysis, idealization, abstraction, retrospective, synthesis and concretization; expert analytical methods, comparison methods and monographic methods were also used; including logical, systemic and situational approaches. The information base consists of official Rosstat (Federal State Statistics Service) data, documents of the executive authorities regulating the activities of enterprises in the field of beef stock farming, information on Internet publications, publications in trade magazines, and materials of scientific and practical conferences corresponding to the specialization of the scientific research.

\section{Results and Discussion}


At the first stage of the research, we define the substantive essence and basic criteria forming the development of definitions and explications of the categories "innovation" and "innovative development" as the key concept for determining the various components of the subject area of the present scientific research. Scientific studies in their historical retrospect proved that the work of N. Kondratieff [21] served as a great stimulus for the promotion and intensification of scientific research in the field of innovation and development. Scientific views and interpretations of the subject area with the tasks by N. Kondratiev played an extraordinary role in the formation of theories and concepts by J. Schumpeter, who understood the category "innovation" as the "new configurations and combinations of structure, qualitative changes in terms of functionality and dynamics of production system development". In his scientific treatise "Theory of Economic Development", this scientist has formed five basic formations of innovations: the emergence of a new product and/or consumer; here the scientist referred to a new type of product, which is interpreted as consumer novelty; development, testing and use of new methods and approaches in production; discovery and development of a new market niche; the acquisition of a new source of raw materials and material resources; transformation of the organization and management system in terms of structural content and functionality $[12,17]$. As our study showed, the category of "innovation" in domestic and foreign scientific practice is often interpreted from different positions and understandings of its explication.

So, I. Cooke and P. Mayers define innovation as the process of transforming an idea into a finished product with different qualities and its implementation in the consumer market [7].

A similar understanding of the substantive essence of this subject under study is presented in a number of scientific papers $[15,16,18,19,28,29]$ devoted to the improvement of innovation management processes, where innovation is interpreted, for the most part, as the process of transition of an invention (novation) into economic content in the form of a final result (net income).

M. Dodgson emphasized that innovations include the scientific, technical and technological, organizational, managerial, financial, economic and regulatory aspects that orient the latter to a commercial result expressed in the growth of the capitalization of the research object [8].

Eerola A., Feller I., Killoren R., Eyerly R. note: “... the category of "innovation” has its application in two conceptual meanings: firstly, to describe a new product, process or system, and secondly, to describe research in the field of design, evaluation, analysis and development of a new product or process. In the latter case, the category "innovation process" is applied $[11,14,20]$.

Consequently, the key feature of innovation is its qualitative change and application in practice with obtaining good economic income (profit), and an invention which was designed, but not implemented in practice and not brought to the consumer market: it is defined as "novation" [4].

Thus, in the general understanding of the quintessence of the category "innovation", it is worth noting that this term describes the result of the practical application of a qualitatively new scientific, technical, organizational, economic, production and/or other solution that 
ensures breakthrough development and/or qualitative and quantitative changes of high intensity of any process and/or phenomenon (positive synergy).

Turning to the applied research level (beef stock farming), taking into account the basic aspects of the stated theme, it should be noted that an increase in the level of innovation and socio-economic efficiency, as well as the quality of meat products, can be achieved on the basis of a comprehensive solution of interrelated problems. The basic directions for the decision-making of a recommendatory nature are illustrated in Figure 1.

Improving the technological infrastructure of livestock facilities with innovative equipment and technologies

Improving the livestock breeding technologies (cattle, sheep and goats), pigs and poultry

Improving the organizational and economic conditions of inter-sectoral interaction (cooperative processes)

Capacity development of the branch through highly productive animals

Increasing the level of provision of livestock farms with high-quality balanced feed

Addressing the issues of shortage of highly qualified personnel, increasing the level of environmental safety of products, resource saving and complex processing of secondary raw materials and waste

Fig 1. Applied solutions to the basic problems of the development of the beef stock farming sector in the agro-industrial complex in terms of increasing its innovativeness and the implementation of projects for its modernization

Modernization and innovative transformations of existing livestock facilities in the modern historical period are of great economic, social, demographic, environmental and political importance since their implementation will allow:

-systematically update the material and technical base (machinery, equipment, automatic control systems, equipment for livestock facilities), replacing the morally obsolete and worn-out production means with innovative types of equipment. All this will contribute to the growth of labour productivity, reduction of direct and indirect production and management costs, as well as create favourable conditions and effective incentives to improve the quality and safety of products;

-improve the technology of farming animals (livestock management and feeding), the technology of carrying out processes taking into account new scientific results on methods of management and feeding, veterinarian and sanitary and environmental standards and 
requirements excluding the spread of pathogenic microflora and pollution of soil, water, air by harmful emissions during the production process;

-successfully adapt modern models and tools for mechanization and automation of technological processes, design and technical planning solutions to improve the productivity of animals, as well as to streamline resource consumption processes (feed, electricity, water, heat, labour);

-reduce the volume of investments in the modernization and expansion of existing livestock farms in comparison with the construction of new facilities in new areas;

-significantly increase production and successfully solve the tasks of import substitution policy, which is directly related not only to food security but also to the national security;

-provide with workplaces the settlements adjacent to the facilities of the industry, which will contribute to the preservation of the peasant-rural way of life, as well as social stability and sustainable balance in the development of our country in the aspect of administrative and territorial planning;

-increase the efficiency of using natural forage lands, as well as to increase the yield of agricultural crops based on the use of environmentally friendly agricultural technologies [1, $3]$.

At present, the production potential modernization for the beef stock farming industry, like no other activity, needs to create a new organizational environment for scientific and technical information based on electronic computing resources and allowing not only to accumulate, systematize, synthesize and preserve the existing knowledge base, but also to provide a positive impact on the availability, prevalence and generation of new information support for the process of production system modernization.

As the empiric shows, in the course of organizing a unified system of information data, the most promising are integrated information systems based on the iterative preparation of information, its output and repeated use in relevant projects. All this creates conditions for improving the quality of information services for consumers, and also allows automating the formation collecting and processing process related to the modernization of livestock farms. In a generalized form, they should be formed and implemented on the same software and hardware principles: unity and proportionality of linguistic means used in the most valid information retrieval modules; the availability of resources to ensure the collection and storage of industry-specific information; ensuring the integrity of the information and communication environment (links); organization and functioning of information databases based on common principles and approaches; the most effective practical application of ready-made algorithms for solving production and economic problems [2, 27]. The implementation of these principles in practice will contribute to the accumulation of industry databases into a single information resource in the context of various levels of management: local, regional and federal.

The experience of the Central Federal District constituent entities (Voronezh and Tver regions) shows that the forms for describing information resources should be capacious in content, very simple and understandable for a potential consumer. That will ensure a high degree of their development and utility [4]. 
A universal form of this type should be an information classifier. The mode of access to it should be free and not have explicit and/or hidden restrictions. Having mastered the information classifier, the consumer determines the place of the information source and communicates with the author of the information resource. To improve the efficiency of search and access to sectoral information in the Voronezh and Tver regions, resource centres at the district level were organized to implement collective access and search for information. They used CALS technologies and SLBA-tools as instrumental software. CALS-technologies provide support for selecting and providing information in a continuous mode, as well as provide unified approaches to managing the interaction of all participants in the discussion platform: the customer, supplier/manufacturer and final consumer of products. The database management tool in multi-access resource centres is DBMS: Oracle, Informix, Sybase, MS SOL, IBM DB2, which allows data (parameters) to enter repeatedly into the information environment, have a unified interface, present data in various formats, ensure consistency data in relation to applications of different types, provide remote access to information, perform teamwork support, and also translate information for public access through applied software packages in the World Wide Web $[2]$.

The need to update the used and mostly obsolete and physically worn-out machinery and equipment, especially on farms for sheep and cattle management, is due to the fact that in the last 8-10 years the update rate did not exceed $2.5-3.0 \%$ per year instead of $13-15 \%$ according to regulations. The analysis of functioning livestock farms (cattle, pigs) built in accordance with the model projects developed as early as 1985-1990, showed that there are no facilities and workshops for processing organic waste, storing feeds and preparing feed mixtures, what does not allow obtaining high-quality feed mixtures, to prepare organic fertilizers and to meet modern environmental requirements $[25,26]$.

The overwhelming majority of projects on which the construction of existing beef stock farming enterprises was carried out, were developed in the 90 s of the last century, and the technological modes for performing production processes, management and feeding animals were based on the results of 25-30 years old scientific research. They do not take into account new achievements of science in the field of zootechnics, feeding, veterinary medicine, economics, organization, planning, ecology, mechanization and automation, as well as resource saving. Therefore, the preparation and implementation of programs for the comprehensive modernization of existing facilities should be aimed at improving and enhancement of all production factors of in order to improve efficiency, competitiveness and quality of meat products, increase its output and rational use of all types of resources.

Scientific and applied research carried out in recent years on the justification and application of the best available technologies (BAT) in the European Union and Russia (the development of information and technical reference books) is aimed at identifying requirements and defining regulatory-acceptable requirements in the production of various types of products that meet international standards quality management [3, 24]. The transition to the principles of the best available technologies in our country is carried out in accordance with the Doctrine of Food Security of the Russian Federation and the "Set of measures aimed at avoiding the use of obsolete and inefficient technologies, the transition to the principles of accessibility and the introduction of advanced technologies". The 
objective need to modernize the beef stock farming in the current market economy was confirmed by a number of reasons and features, illustrated in Figure 2.

THE REASONS AND FEATURES OF THE MODERNIZATION OF THE LIVESTOCK INDUSTRY MEAT PRODUCTION SUBCOMPLEX OF THE RUSSIAN FEDERATION

A significant underrun of the livestock sector in the terms of the development, adaptation and
application of innovations
The high importance of increasing the pace of livestock development and the production volume of
The inefficiency of a number of federal and industry programs related to the innovative development of
Unsolvedness of a number of problems related to environmental protection and the ecologization of
modern agricultural technologies, including in the field of animal husbandry
thechnologies for management and feeding animals, increasing the conversion rate and animal welfare,
thethods and means of mechanization and automation, alternative energy, resource saving, raw
materials processing and finished product storage
The low development level of integrative and cooperative interaction between participants of the single:
agro-industrial market in the aspect of the functioning of production associations, exchange of
experience and information, feed production and implementation of resource-oriented technological
solutions

Fig 2. The reasons and features of the modernization in the livestock farming industry of the meat production subcomplex in the Russian Federation [7].

Studies show that high efficiency of beef stock farming modernization can be achieved only with its complex implementation, including all elements of production and management: food supply, reconstruction of buildings and structures, construction of new facilities, use of highly efficient machinery and equipment complexes, improving the system of organization, planning and management in the field of HR-, PR- and ITmanagement.

When modernizing pork production complexes, it is necessary to ensure the creation of optimal conditions for all age groups of animals to achieve maximum productivity and realize reproductive functions: the required area for stress-free housing, feeding ration, 
young stock livability; water, temperature and humidity, clean air and air exchange rate, and illumination in the rooms, provision of balanced feed, their quality, veterinary and sanitary inspection. Moreover, there should be used unified machine equipment, balanced feed, automated feed stations for sows, automatic microclimate control systems, cleaning premises from organic waste by means of conveyor belts, and separating waste into composite fractions using filter-type centrifuges, organic fertilizers and compound feed production plants with productive capacity from 1.5 to $5.0-7.0 \mathrm{t} / \mathrm{h}$.

The implementation of the outlined measures on mechanization and automation of production processes at the facilities being modernized will make it possible to increase labour costs for obtaining 1 centner of pig weight gain - up to $1.5-3.5$ people $\cdot h$, gain of cattle - up to 6.5-7.0 people h; feed consumption per $1 \mathrm{~kg}$ of pig weight gain - up to 3.0-3.5 centners of feed; the weight gain profitability for pigs should be at least $25-30 \%$. The productivity of animals due to the optimization of housing conditions and feeding rations will approximately increase by $15-20 \%$. Also, all this will contribute to reducing costs for the reproduction of breeder's stocks $[1,3,23$.

\section{Conclusions}

Thus, the study allowed us to form a holistic view of the state, nature and features of the livestock enterprises functioning in the meat production subcomplex of the Russian Federation in terms of carrying out program-targeted measures to modernize production complexes and associations, as well as to determine the direction for the formation of an innovative strategy for the development of this sector in the agro-industrial complex.

The developed set of decisions, conclusions and recommendations of both scientific and theoretical, and also applied nature creates favourable environment and organizational and managerial tools for the implementation of projects in the field of modernization of the beef stock farming sector of the agro-industrial complex for industry specialists, government regulatory structures, as well as scientific personnel. These projects should be based on the following group of measures: justification of the most efficient, technical and technological solutions for specific production conditions (specialization and concentration of production, condition of buildings and structures, type of marketable products); preparing of design and estimate documentation with the inclusion of directions on improving technology and technical base; elaboration of business plans for the modernization; financing methods, the organization and timing of the implementation; clarification of the organizational and economic plans for the development of production (expansion of volumes, change in specialization, need for personnel, financial and material resources (feed, animals), economic indicators of the modernization effectiveness, the payback period).

Research practice has proven that the fulfilment of tasks related to increasing the productivity and sustainability of domestic meat livestock farming is impossible without accelerated modernization of the industry's production systems using high-performance equipment, modern technologies and alignment with the latest science and technology developments, requirements and standards, technical specifications of buildings and structures. All this is verified by the practice of forming a single information resource on the territory of the municipal districts in the Voronezh and Tver regions, which contributes to the modernization of not only large meat and animal husbandry complexes, but also peasant farms. 


\section{References}

1. Buklagin, D. S. (2017). On the need to develop industry standards for technologies and technological processes in the field of agriculture. Scientific and information support for innovative development of the agro-industrial complex. Proceedings of the IX International Scientific and Practical Conference "InformAgro-2017". Moscow, 105-111.

2. Voytyuk, M. M. \& Suraeva, E. A. (2016). Formation of information support for the modernization of the livestock industry in the region. Bulletin of the All-Russian Research and Design-Technological Institute for the Mechanization of Livestock, 2(22), 200-2013.

3. Voytyuk, M. M. (2012). Implementation of investment projects on infrastructure arrangement in rural areas. Moscow., $168 \mathrm{p}$.

4. Voytyuk, M. M. \& Voytyuk, V. A. (2012). Regional experience in the formation of a single information resource for rural housing construction. Nikon readings, 17, 200203.

5. Morozov, N. M. \& Morozov, I. Yu. (2018). Economic and social problems of livestock modernization: economic feasibility and implementation methodology. Bulletin of the All-Russian Research and Design-Technological Institute of Animal Life Mechanization, 1(29), 4-11.

6. Turyansky, A. V., Anichin, V. L., Dobrunova, A. I., \& Epifantsev, N. P. (2019). Onfarm agro-industrial integration is a promising direction for the development of rural territories. Economics of agricultural and processing enterprises, 4, .22-25.

7. Ian, C., \& Mayers, P. (1996). Introduction to innovation and technology transfer Boston: Artech House. Inc., 1996.-235 p.

8. Dogson, M. (2003). The Management of Technological Innovation: an international and strategic approach. Oxford University Press.

9. Dorofeev, A. F., \& Dobrunova, A. I. (2015). The cluster approach to development of rural areas. Вестник аграрной науки, 53(2).

10. Dosi, G. (1997). Opportunities, incentives and the collective patterns of technological change. The economic journal, 107(444), 1530-1547.

11. Eerola, A. (1996). Creating and communicating technology foresight. the book "Innovation Systems and Competition", ed. by O. Kuusi, ETLA Series B, 125.

12. Evans, P. B., \& Wurster, T. S. (1997). Strategy and the new economics of information (pp. 71-82). New York, NY: Harvard Business Review.

13. Feller, I. (1997). Federal and state government roles in science and technology. Economic Development Quarterly, 11(4), 283-295.

14. Fichman, R. G., \& Kemerer, C. F. (1997). The assimilation of software process innovations: An organizational learning perspective. Management science, 43(10), 1345-1363. 
15. Gerrard, J. (1996). The importance of international cooperation in science and technology. SRA Journal, 28(1), 29.

16. Giget, M. (1997). Technology, innovation and strategy: recent developments. International Journal of Technology Management, 14(6-8), 613-634.

17. Harryson, S. J. (1997). How Canon and Sony drive product innovation through networking and application focused R\&D. Journal of Product Innovation Management: AN INTERNATIONAL PUBLICATION OF THE PRODUCT DEVELOPMENT \& MANAGEMENT ASSOCIATION, 14(4), 288-295.

18. Howells, J. (1997). Rethinking the market-technology relationship for innovation. Research Policy, 25(8), 1209-1219.

19. Jonash, R., \& Sommerlatte, T. (2001). The innovation Premium: How next generation companies are achieving peak performance and profitability. Basic Books.

20. Killoren, R., \& Eyerly, R. W. (1997). A brave new world of virtual organization: Creating a distributed environment for research administration. SRA Journal, 29(1/2), 25.

21. Measuring Innovation, Boston Consulting Group, Inc. 2006.

22. Merenkov, I. N., Turyansky, A. V., Dobrunova, A. I., Prostenko, A. N., \& Oliva, L. V. (2018). State support improvement for ecological land-use in terms of transition to rural territory sustainable development. Revista Amazonia Investiga, 7(15), 13-19.

23. Ardakani, M. P., Lashkarian, A., \& Sadeghzadeh, M. (2015). The Translatability/Untranslatability of Poetics: Eliot's" Ash Wednesday" and its two Persian translations. UCT Journal of Social Sciences and Humanities Research, 3(1), 52- 60 .

24. Mirzaei, B. (2017). Investigation of Antibacterial Effects of Medicinal Plants on Bacterial Pathogens of Patients. Medbiotech Journal, 01(02), 85-9.

25. Krishtiana, N., \& Kimatova, L. (2018). Antibacterial Study and Green Preparation of Silver Nanoparticles through Some Plants. Medbiotech Journal, 02(02), 54-8.

26. Shirvani, M., Mohammadi, A., \& Shirvani, F. (2015). Comparative study of cultural and social factors affecting urban and rural women's Burnout in Shahrekord Township. UCT Journal of Management and Accounting Studies, 3(1), 1-4.

27. Melo, R., Sobrinho, V. D. P. F. M., Filho, I. J. D. M., Feliciano, F., \& Maciel, P. R. M. (2018). Redundancy Mechanisms Applied in Video Streaming Service on Eucalyptus Cloud Computing Infrastructures. Journal of Information Systems Engineering \& Management, 3(3), 25.

28. Tasnim, T., \& Farasat, A. (2018). The Bioproduction of Ethanol through Isolation of Some Local Bacteria. Medbiotech Journal, 02(03), 132-5.

29. Selomo, M. R., \& Govender, K. K. (2016). Procurement and Supply Chain Management in Government Institutions: A Case Study of Select Departments in the Limpopo Province, South Africa. 